\title{
SUASANA BELAJAR BARU DENGAN MODEL PEMBELAJARAN LAWATAN SEJARAH UNTUK MENUMBUHKAN KESADARAN SEJARAH KEPADA SISWA
}

\author{
Muhammad Fajar Hairullah \\ Program Studi Pendidikan Sejarah FKIP Universitas Lambung Mangkurat \\ Banjarmasin \\ Email: 1710111110010@mhs.ulm.ac.id
}

\begin{abstract}
Abstrak: Realita di lapangan saat ini pengajaran di sekolah pembelajarannya masih belum menampakan dalam inovasi pengajaran. Terpengaruh oleh metode yang hanya menerangkah dengan ceramah. Metode belajar dewasa ini sebagai alat bagaimana proses belajar itu berjalan sebagaimana mestinya. Seorang siswa bisa menikmati seorang guru menyajikan materi dengan berbagai metode ketika mengajar di kelas. Sebagai alternatif agar pembelajaran sejarah lebih menarik dan membuat siswa lebih aktif, maka dapat digunakan metode lawatan sejarah. Metode lawatan sejarah ini memberikan tantangan pada siswa ketika belajar dengan objek di luar kelas. Pengajaran yang berhasil merupakan sebuah pencapain yang penting dari tujuan pendidikan. Sebuah pengajaran bisa dikatakan adanya indikator dari seorang guru dan siswa sebagai peserta didik. Minat itu sendiri dipengaruhi oleh faktor psikis, fisik dan lingkungan, yang ketiganya ini saling melengkapi.

Kesadaran sejarah merupakan suatu kesadaran dalam diri manusia untuk mengetahui bagaimana asal mula mereka dilahirkan dan bagaimana kejadian masa lalu yang pernah di alami oleh diri sendiri maupun kelurga terdekat. Dengan pembahasan yang jauh kesadaran sejarah dapat berupa bentuk rasa ingin tau sangat mendalam akan kejadaian masa lampau di seluruh Dunia atau Negara sendiri. Dimana rasa ingin tau itu menjadi suatu hasrat untuk mengkaji lebih dalam lagi bagaimana sejarah itu berkembang dan menghasilkan suatu solusi atau memberi suatu penjelasan akan kejadain dimasa lampau dan mengatasi permasalahan di masa sekarang.
\end{abstract}

Kata kunci: Lawatan Sejarah, Model Pembelajaran, Kesadaran Sejarah

\section{PENDAHULUAN}

Permendikbud No 59 Tahun 2014 tentang kurikulum 2013 menyatakan pembelajaran sejarah tingkat SMA, Guru dituntut lebih kreatif 
dan inovatif, sehingga ranah keterampilan, pengetahuan dan sikap dapat terpenuhi dalam setiap pembelajaran di kelas. Sehingga solusi yang ditawarkan untuk memperbaiki pendalaman materi pada siswa, tidak hanya mempelajari teori semata tetapi dengan memanfaatkan situs peninggalan sejarah yang terdapat disekitar kita atau daerah kita dapat menjadi sumber belajar di SLTA/SMA yang akan merangsang stimulus siswa dalam kegiatan belajar mengajar.

Sartono Kartodidjo (1988) berpendapat; bahwa dalam rangka pembangunan bangsa, pengajaran sejarah tidak semata-mataberfungsi untuk memberikan pengetahuan sejarah sebagai kumpulan informasi fakta sejarah tetapi juga bertujuan menyadarkan anak didik atau membangkitkan kesadaran sejarahnya. Untuk mencapai tujuan tersebut maka sejarah yang diajarkan haruslah sejarah yang mengedepankan nilainilai kehidupan, bukan sejarah hapalan yang hanya menyuguhkan nama, tempat, angka tahun dan peristiwa semata. Kendatipun unsur-unsur tersebut tidak dapat ditinggalkan dari pembelajaran sejarah, akan tetapi bukan berarti pembelajaran yang dilakukan hanya memfokuskan pada halhal tersebut, yang akan menjadikan pembelajaran sejarah menjadi kering dari makna dan tidak memberikan penyadaran terhadap individu pembelajar.

\section{SUASANA PEMBELAJARAN SEJARAH YANG MENYENANGKAN}

Aktivitas belajar bisa dibedakan antara yang bersifat kuantitatif dan yang kualitatif. Yang pertama lebih menekankan upaya mencapai informasi (fakta) sebanyak-banyaknya sedang yang kedua (kualitatif) lebih bertekanan pada mengembangkan kemampuan belajar/berpikir (learn how to learn). Dalam kaitan ini, dalam hubungan proses pendidi-kan di sekolah Soedjatmoko pernah menegaskan bahwa dalam konsep belajar secara kualitatif jantung dari sekolah bukanlah hanya terlihat dari kegiatan belajar di kelas oleh guru. Justru yang lebih utama adalah kegiatan berupa pemanfaatan perpustakaan, lab, maupun kegiatan di lapangan.

Dengan kata lain, dalam belajar secara kualitatif proses pembelajaran yang lebih mendasar bukan hanya interaksi guru dengan murid, tetapi in-teraksi murid dengan berbagai sumber belajar (berbagai bahan bacaan, nara sumber, lingkungan alam, sosial budaya, dan lain-lain). Belajar Sejarah yang sarat dengan unsur-unsur estetika dan seni, sangat menjanjikan bisa memberikan kesenangan dan hiburan bagi siswa. Guru hanya tinggal memilih metode yang tepat dalam kegiatan pembelajaran, sehingga unsur-unsur estetika dan seni yang terkandung dalam sejarah bisa dimunculkan dan menarik bagi siswa. Melalui penulisan kisah sejarah 
yang menarik, pembaca dapat merasa terhibur.

Gaya penulisan yang hidup dan komunikatif dari sejarawan terasa 'menghipnotis' pembaca. Pembaca merasa nyaman membaca buku tulisannya. Daya tarik penulisan kisah sejarah tersebut membuat pembaca menjadi senang.Membaca menjadi media hiburan dan rekreatif.

Peristiwa masa lampau memang sudah berlalu, tetapi yang lampau itu masih berpengaruh terhadap masa sekarang sehingga orang dapat mengambil suatu kebijakan untuk kepentingan sekarang dan masa depan. Di sinilah pentingnya pembelajaran dengan menggunakan suatu strategi, termasuk dalam belajar sejarah. Belajar tidak sekadar bagaimana kita belajar, tetapi juga bagaimana belajar untuk belajar itu sendiri

Ada beberapa hal yang perlu diperhatikan ketika belajar sejarah yaitu:

1. Sejarah Itu Hasil Rekonstruksi Masa Lalu

Objek kajian sejarah adalah masa lalu, utamanya berkenaan dengan apa yang dilakukan, dipikirkan dan dihasilkan oleh manusia. Mengapa harus dipelajari? Ini berkaitan dengan kepentingan masa kini, setidaknya agar manusia mengerti dan memahami keberadaan dirinya. Karena apa yang terjadi di masa kini sangat berkaitan dengan apa yang telah dilakukan oleh manusia di masa lalunya. Bagi masa depan setidaknya hal tersebut dapat dijadikan acuan atau pembelajaran. Sehingga kualitas hidup manusia dari waktu ke waktu menjadi lebih baik.

Berdasarkan hal tersebut maka poin utama dalam mempelajari sejarah adalah belajar tentang nilai-nilai kehidupan. Kehidupan manusia di masa lalu sebagai sumber belajarnya. Seperti pepatah bilang "pengalaman adalah guru terbaik". Rentang waktu masa lalu sebagai objek kajian sejarah tidak terbatas. Sejam, sehari, seminggu, sebulan, setahun, seabad, seribu atau bahkan sejuta tahun yang lalu, semuanya adalah masa lalu. Sementara kita, sebagai orang yang mempelajari peristiwa di masa lalu tersebut hidup di masa Sekarang.

Jika masa lalu yang akan dipelajari itu belum lama, maka sumber yang dapat dipakai tentunya masih banyak. Namun jika yang dikaji ribuan tahun yang lalu, tentu sumbernya sangat terbatas. Tidak ada yang bisa menceritakan apa yang telah terjadi. Kalaupun ada, biasanya berupa tradisi lisan, siapa yang dapat memverifikasi kebenarannya? Bahkan seringkali hanya berupa benda, atau bekas-bekas aktivitas manusia yang berserakan. Tak ada cerita apapun yang tersampaikan dari sisa-sisa tersebut.

Para sejarawanlah yang melakukan rekonstruksinya untuk kita. Menggunakan berbagai pendekatan, untuk menemukan sebuah 
kesimpulan. Proses akademik yang menjunjung tinggi kajian ilmiah dan objektivitas menguji kesimpulan. Hasilnya menjadi kebenaran yang kemudian kita yakini, itulah yang pernah terjadi di masa lampau. Itulah sejarah.

Sebagai hasil dari kajian ilmiah, sejarah tentu selalu memiliki ruang untuk diuji kebenarannya. Selalu terbuka bagi Analisa dan kajian-kajian baru. Karena begitulah ilmu pegetahuan. Tidak mentabukan pada satu tafsir kebenaran. Disinilah, sejarah selalu menarik. Karena itu berarti siapapun memiliki kebebasan untuk ikut terlibat menganalisis apa yang telah terjadi dari sudut pandang yang dapat kita pahami.

\section{Rekonstruksi Melahirkan Pikiran Kreatif}

Seperti apapun sisa yang didapat dari kehidupan masa lalu manusia itu, sejarawan dituntut dapat mengungkapkan apa yang terjadi. Mulai dari peristiwa, pelaku, motif, cara hidup atau apa saja dibalik sisa-sisa yang tertinggal tersebut. Berperan seperti detektif, sejarawan melakukan rekonstruksi, yaitu membangun kembali suasana kehidupan masa lalu dengan berdasarkan sumber yang tersedia. Mereka mencoba menginterpretasi setiap sumber yang ada.

Secara ilmiah, terdapat beberapa tahap guna mendapatkan kesimpulan objektif. Pertama adalah tahap heuristic. Pada tahap ini, sejarawan mengumpulkan sebanyak mungkin data, peninggalan, sumber yang akan diteliti. Setelah sumber diperoleh, langkah berikutnya dimulai, sumber dipilah-pilah dan diurutkan menggunakan tingkat kegunaannya. Sumber-sumber yang sangat penting, sangat menunjang bagi penelitian, dimasukkan sebagai sumber primer. Selebihnya dapat dimasukkan sebagai sumber sekunder dan seterusnya.

Untuk menjadikan proses kedua ini dapat dengan mudah dilakukan. Sejarawan dapat menggunakan kritik internal dan kritik eksternal untuk sumber-sumber yang didapat. Prosesnya sederhana, jika sumbernya berupa buku, lihat pengarangnya, penerbitnya, memiliki track record kapsitas apa tidak. Itu yang disebut kritik eksternal. Belum cukup, baca isinya, pahami maksudnya. Saling bertentangan tidak kajiannya. Isinya sesuai tidak dengan logika-logika yang selama ini hidup dan berkembang di masyarakat. Jika ada pertentangan, cari pembanding yang relevan. Inilah kritik internal.

Tahap ketiga, adalah tahap sejarawan menafsirkan apa yang sebenarnya terjadi. Pada konteks inilah imajinasi diperlukan. Imajinasi sejarawan yang didasarkan data dan tentu saja dukungan ilmu-ilmu yang 
lain digunakan untuk menghadirkan masa lalu yang kemudian dibuatkan deskripsinya, dan pada akhirnya pembaca atau manusia masa kini dapat mengerti seperti apa masa lalu di balik sisa-sisa peninggalan tersebut.

Realitas demikian tentu membutuhkan kreativitas dalam berpikir, dan kreativitas seperti itu bukan merupakan monopoli sejarawan saja, melainkan bagi kita yang mempelajari sejarah. Memadukan antara penggalan fakta yang satu dengan fakta lainnya membutuhkan daya analisis yang membuat kita dicerdaskan. Belum lagi jika kita juga turut mencoba mencari kemungkinan-kemungkinan yang bisa saja terjadi namun belum diungkap oleh sejarawan penulisnya, pasti lebih mengasyikkan dan hal seperti ini sangat dianjurkan dalam mempelajari sejarah. Sebab kebenaran sejarah itu tidak tunggal.

Misalnya saja saat mempelajari peninggalan kerajaan Mataram Kuno. Sumber pembahasan adalah Candi Prambanan atau Borobudur. Dengan menggunakan imajinasi kita bisa melakukan eksplorasi lebih lanjut, tidak sekedar mengetahui bahwa kedua candi tersebut merupakan peninggalan kerajaan Mataram.

Melalui pertanyaan-pertanyaan kritis, kita bisa mengetahui bagaimana kehidupan masyarakat pada saat tersebut. Seperti, bagaimana candi itu di bangun, ukuran seperti apa yang di gunakan, siapa yang merancang, siapa yang jadi pekerja, bagaimana suplai logistik bagi para pekerjanya, dimana mereka tinggal, bagaimana manajemen operasionalnya, dan masih banyak lagi pertanyaan yang bisa di ajukan.

Dengan imajinasi dan data yang tersedia kita dapat menjawab berbagai hal dari pertanyaan-pertanyaan tersebut. Tentu jawaban-jawaban yang ada adalah jawaban spekulatif, dan perlu pembuktian melalui berbagai argument pembanding, dan tidak kalah pentingnya adalah hal-hal yang bersifat akademis.

Salah atau benar jawaban yang bisa dimunculkan bukanlah hal terpenting, bagi kita yang belajar sejarah, namun kemampuan membingkai serpihan menjadi sebuah deskripsi yang bermakna menjadi lebih penting. Karena, bukan sejarawan. Dengan hal-hal semacam ini, tentunya kreativitas berpikir menjadi terasah.

Berdasarkan hal tersebut banyak ilmuwan kemudian sepakat, bahwa selain sains, sejarah juga adalah seni. Sebab tidak sekedar pemaparan data atau fakta, namun dalam mendeskripsikan hasil rekonstruksi perlu di dukung imajinasi. Intuisi dan juga Bahasa, agar hasil rekonstruksi tidak kering. Namun dapat menghadirkan masa lalu menggunakan deskrispsi yang dihidupi para pembacanya di masa kini. 
Jika demikian tentu sejarah tak ubahnya seperti seni-seni yang lain. Tahap inilah yang dalam kajian ilmiah disebut sebagai historiografi.

\section{LAWATAN SEJARAH SEBAGAI MODEL PEMBELAJARAN GUNA MENINGKATKAN KESADARAN SEJARAH}

Menurut Susanto Zuhdi lawatan sejarah adalah suatu program penjelajahan masa lalu melalui kunjungan ke tempat-tempat bersejarah. Tempat bersejarah tersebut dapat berupa makam tokoh, tempat pengasingan, komunitas masyarakat, dan juga pusat-pusat kegiatan ekonomi (Lestariningsih, 2007:3). Selain itu, pengajar dapat memanfaatkan museum daerah terdekat sebagai sasaran lawatan sejarah. Di dalam museum jelas sekali terdapat berbagai artefak peninggalan masa Hindu-Buddha dan beberapa diorama penyajian peristiwa bersejarah masa prasejarah maupun Indonesia modern (Hartatik, 2007:9). Menurut Cahyo Budi Utomo (Makalah Seminar Sejarah, 2007), Lawatan Sejarah adalah suatu kegiatan perjalanan mengunjungi situs bersejarah (a sejarah to lawatan sites).

Jika mencermati uraian di muka, khususnya tentang pengembangan metode pembelajaran berbasis teori belajar yang berkembang, maka lawatan sejarah dapat dikembangkan sebagai metode pembelajaran sejarah baik dengan basis teori behavioristik, kognitif, maupun konstruktivistik. Tinggal bagaimana guru dan atau murid mengemasnya. Tentu saja, kalau kita mengikuti perkembangan baru. Terutama paradigma baru yang dijadikan rujukan yang mendasari penyelenggaraan pendidikan di Indonesia, yang dituangkan baik pada UU tentang Sisdiknas maupun Peraturan Menteri tentang Standar Kompetensi danImplementasinya, maka sangat jelaslah bahwa paradigma pembelajaran kontruktivisme menjadi pilihan utamanya.

Mengamati perkembangan penyelenggaraan pendidikan di Indonesia, gejala diterimanya paradigma konstruktivisme dan tren pembelajaran quantum sungguh menggembirakan. Hal ini terbukti dari mulai maraknya kegiatan-kegiatan pendidikan baik formal (sekolah) maupun non formal (pelatihan, workshop, atau bahkan seminar lokakarya) yang dikemas dalam bentuk Edutainment. Kita sudah lama mengenal istilah learning by doing, maka learning by experiencing adalah ungkapan yang tepat untuk Menggambarkan "Edutainment". Edutainment yaitu sebuah konsep yang saat ini sedang dikembangkan oleh berbagai lembaga pendidikan formal (sekolah) maupun non formal (lembagalembaga yang menyelenggarakan pelatihan, workshop, atau seminar). 
Bahkan dinegara maju, edutainment telah ditopang oleh teknologi yang maju, sehingga sebutannya menjadi edutainment and technotainment (Edutechnotainment). Progam ini diakui telah membuka sumber daya baru, perkakas dan strategi untuk mengangkat kemampuansiswa ke tingkat yang lebih tinggi. Edutainment adalah akronim dari "education and entertainment".

Dapat diartikan sebagai progam pendidikan atau pembelajaran yang dikemas dalam konsep hiburan sedemikian rupa, sehingga tiap-tiap peserta hampir tidak menyadari bahwa mereka sebenarnya sendang diajak untuk belajar atau untuk memahami nilai-nilai (value), sehingga kegiatan tersebut memiliki nuansa yang berbeda dibandingkan dengan pembelajaran biasa. Edutainment dapat digunakan untuk mengemas metode pembelajaran melalui lawatan sejarah. Aplikasinya tergantung dari kebutuhan dan impact yang diharapkan oleh peserta. Lawatan sejarah yang dikemas dalam Edutainment akan menjadi lebih menarik bagi peserta. Sebenarnya lawatan sejarah ini hanyalah kendaraan saja yang diperuntukan untuk semua yang belajar sebagai pecinta sejarah.

Hal tersebut secara teoritik bukan hal yang mengherankan. Ada faktor-faktor kunci sukses yang terkumpul dalam diri peserta, seperti positive mental attitude, knowledge, skills, dan habit. Melihat faktor-faktor tersebut, maka pendekatan penting dikembangkan adalah memberikan motivasi pada faktor positive mental attitude. Tekniknya dilakukan dengan menggali keinginan seseorang yang paling dalam dan menjadikannya sebagai main need ataumain good. Sedang outputnya nanti adalah momentum seseorang untuk berubah. dapat digunakan untuk mengemas metode pembelajaran melalui lawatan sejarah. Aplikasinya tergantung dari kebutuhan dan impact yang diharapkan oleh peserta. Lawatan sejarah yang dikemas dalam Edutainment akan menjadi lebih menarik bagi peserta. Sebenarnya lawatan sejarah ini hanyalah kendaraan saja yang diperuntukan untuk semua yang belajar sebagai pecinta sejarah.

Menurut Widja, (1989:556) Kesadaran sejarah adalah refleksi sikap yang bersumber pada kondisi kejiwaan yangmenunjukkan tingkat penghayatan, pada makna serta hakekat sejarah. Menurut Suyatno Kartodirjo (2000: 1-7), kesadaran sejarah pada manusia sangat penting artinya bagi pembinaan budaya bangsa. Kesdaran sejarah dalam kontek ini bukan hanya sekedar memperluas pengetahuan, melainkan harus diarahkan pula kepada kesadaran penghayatan nilai-nilai budaya yang relevan dengan usaha pengembangan kebudayaan itu sendiri. Dalam kaitan dengan proses belajar-mengajar di forum- forum akademis, suatu proses pengajaran sejarah hendaknya dapat membantu membangkitkan 
kesadaran sejarah para peserta didik. Jika kesadaran semacam itu nantinya bisa dimiliki oleh para peserta didik di berbagai lapisan masyarakat di negeri ini, diharapkan akan terjadi kohesi sosial yang makin erat di antara sesama warga negara, dimanapun berada. (Wardaya, 2008).

\section{PENUTUP}

Lawatan Sejarah bisa dijadikan sebagai opsi dari proses pembelajaran, dimana belajar tidak hanya menekankan kepada upaya mencapai informasi (fakta) sebanyak-banyaknya tetapi juga bertekanan pada mengembangkan kemampuan belajar/berpikir (learn how to learn). Dalam kaitan ini, dalam hubungan proses pendidikan di sekolah bahwa dalam konsep belajar secara kualitatif jantung dari sekolah bukanlah hanya terlihat dari kegiatan belajar di kelas oleh guru. Justru yang lebih utama adalah kegiatan berupa pemanfaatan perpustakaan, lab, maupun kegiatan di lapangan. Dengan kata lain, dalam belajar secara kualitatif proses pembelajaran yang lebih mendasar bukan hanya interaksi guru dengan murid, tetapi interaksi murid dengan berbagai sumber belajar seperti buku, dokumen, situs sejarah dan lain-lain.

\section{DAFTAR PUSTAKA}

Susanto, Heri. 2014. Seputar Pembelajaran Sejarah (Isu, Gagasan dan Strategi Pembelajaran). Yogyakarta : Aswaja Pressindo

Wiwin. 2014. Pengaruh Lawatan Sejarah Terhadap Kesadaran Sejarah Pada Siswa. Semarang: Unnes

Utomo, Cahyo Budi. 2007. Lawatan Sejarah Sebagai Metode Pembelajaran Sejarah. Makalah Seminar Nasional. Semarang: Unnes

Zuhdi, Susanto. 2007. Lawatan Sejarah Sebuah Tawaran Metode Efektif untuk Pembelajaran Sejarah. Makalah Seminar Nasional. Semarang: Unnes

Widja, I Gde. 2018. Pembelajaran Sejarah yang Mencerdaskan : Suatu Alternatif menghadapi tantangan \& tuntutan zaman yang berubah. Denpasar : Universitas Pendidikan Ganesha.

Udin, Irfan. 2013. Lawatan Sejarah Kota Tua Semarang \& Minat Belajar Sejarah Pada Pembelajaran Masa Kolonial di Kelas XI SMAN 3 SEMARANG Tahun Ajaran 2012/2013. Semarang: Unnes

Ayuningtyas, Tantri R. Anissyatul H, dan Rina R. 2018. Pemanfaatan Situs 
Peninggalan Sejarah di Kabupaten Bondowoso sebagai sumber belajar di sekolah lanjutan tingkat atas di Kabupaten Bondowoso. IKIP PGRI Jember

Yudaningsih, Sariyatun, dan Leo Agung S. PENERAPAN MODEL DISCOVERY LEARNING MELALUI LAWATAN SEJARAH UNTUK MENINGKATKAN KESADARAN SEJARAH DAN PRESTASI BELAJAR SISWA KELAS XI IPS 1 SMA NEGERI 1 WURYANTORO KABUPATEN WONOGIRI TAHUN 2015/2016. Semarang : Universitas Sebelas Maret.

Lestariningsih, Amurwani Dwi. 2007. Lawatan Sejarah Sebagai Program Strategis Dalam Meningkatkan Kesadaran Sejarah. Makalah Seminar Nasional (Tidak diterbitkan). Unnes: Semarang.

Widja. 1989. Sejarah Lokal Suatu Perspektif Dalam Pengajaran Sejarah. Jakarta: Departemen Pendidikan dan Kebudayaan

Suyatno Kartodirdjo. 2000. "Teori dan Metodologi Sejarah dalam Aplikasinya", dalam Historika, No. 11 Tahun XII. Surakarta: Program Pascasarjana Pendidikan Sejarah Universitas Negeri Jakarta KPK Universitas Sebelas Maret Surakarta. 